\title{
Pengaruh Kebutuhan Aktualisasi Diri, Penghargaan dan Komitmen Kerja terhadap Kinerja Karyawan di SMK 1 Kedungwuni Kab. Pekalongan
}

\author{
Manajemen Sumber Daya Manusia \\ Indra Ardhi Kurniawan ${ }^{1)}$, Sri Murdiati' ${ }^{2)}$, Setyowati Subroto ${ }^{3)}$ \\ Fakultas Ekonomi dan Bisnis, Universitas Pancasakti, Tegal \\ Indraardhikurniawan@gmail.com, srimurdiati@yahoo.com, titie.putri@gmail.com
}

\begin{abstract}
ABSTRACK
His study aims to To determine the effect of self-actualization on employee performance of SMK 1 Kedungwuni, To determine the effect of appreciation on employee performance of Kedungwuni 1 Vocational High School, To determine the effect of work commitment on employee performance in Kedungwuni Vocational High School self-actualization, appreciation, and work commitment to the performance of employees of SMK 1 Kedungwuni. This research is categorized as survey research, where the instrument of this research is a questionnaire and uses a Likert scale. The population in this study were all employees of SMK 1 Kedungwuni, Kab. There are 30 people in Pekalongan. The samples taken in this study were all 30 respondents in Kedungwuni Vocational High School 1. Test the validity of this instrument using product moment correlation techniques at a significant level of 5\% (0.05) with $r$ table of freedom degrees $=0.361(N=30)$. While the reliability test uses Cronbach Alpha. The analysis technique used is multiple linear regression. This research shows that all statements in the questionnaire with 36 statements have been valid and reliable, so they can be used. And the $R$ Square test results show that the results $R 2=0.644$ means that $64.4 \%$ of employee performance $(Y)$ is influenced by the amount of selfactualization (X1), rewards (X2), and work commitments (X3), the remaining $35.6 \%$ influenced by other factors outside the model.
\end{abstract}

\section{Keywords: Self Actualization, Awards, Work Commitments, Employee Performance.}

\begin{abstract}
ABSTRAK
Penelitian ini bertujuan untuk mengetahui pengaruh aktualisasi diri terhadap kinerja karyawan SMK 1 Kedungwuni, pengaruh penghargaan terhadap kinerja karyawan SMK 1 Kedungwuni, pengaruh komitmen kerja terhadap kinerja karyawan SMK 1 Kedungwuni serta untuk mengetahui pengaruh aktualisasi diri, penghargaan, dan komitmen kerja terhadap kinerja karyawan SMK 1 Kedungwuni. Penelitian ini di kategorikan sebagai penelitian survey, dimana instrumen penelitian ini berupa kuesioner dan menggunakan skala likert. Populasi dalam penelitian ini adalah semua karyawan SMK 1 Kedungwuni Kab. Pekalongan berjumlah 30 orang. Sampel yang di ambil dalam penelitian ini semua sampel yang ada di SMK 1 Kedungwuni sebesar 30 responden. Uji validitas instrumen ini menggunakan teknik korelasi product moment pada level of significant 5\% (0,05) dengan derajat kebebasan $r$ tabel=0,361 $(\mathrm{N}=30)$. Sedangkan uji reliabilitasnya menggunakan Cronbach Alpha. Teknik analisis yang di gunakan adalah regresi linier berganda. Penelitian ini menunjukan bahwa semua pernyataan yang ada di kuesioner dengan jumlah 36 pernyataan telah terjadi valid dan reliabel, maka dapat di gunakan. Dan hasil uji R Square menunjukan bahwahasil $\mathrm{R}^{2}=$ 0,644 berarti bahwa 64,4\% kinerja karyawan (Y) di pengaruhi oleh besarnya
\end{abstract}


aktualisasi diri (X1), penghargaan (X2), dan komitmen kerja (X3), sisanya sebesar $35,6 \%$ dipengaruhi oleh faktor lain di luar model.

\section{Kata Kunci : Aktualisasi Diri, Penghargaan, Komitmen Kerja, Kinerja Karyawan}

\section{Pendahuluan}

Menumbuhkan kinerja yang baik akan muncul aktualisasi diri, dan harus di lihat secara objektif dan tidak di pandang sebelah mata. Seperti yang dikemukakan oleh Sutrisno (2009:126), apabila semua kebutuhan lainnya telah terpenuhi secara memadai, karyawan akan termotivasi oleh kebutuhan akan aktualisasi diri. Mereka akan mencari makna dan perkembangan pribadi dalam pekerjaannya, serta secara aktif mencari tanggung jawab baru.

Fahmi (2015:102), menjelaskan teori Abraham H. Maslow ada 5 (lima) kebutuhan manusia yang harus di susun dalam suatu bentuk hierarki yaitu Physiological needs( kebutuhan fisiologi), Safety needs atau security needs( kebutuhan akan rasa aman),Affection needs atau love needs atau belonging needs( kebutuhan rasa memiliki,sosial, dan cinta), Esteem needs( kebutuhan harga diri), Self-actualization( kebutuhan aktualisasi diri).Dari kelima kebutuhan tersebut yang dapat meningkatkan motivasi bekerja untuk terus berprestasi adalah kebutuhan aktualisasi diri.Pemenuhan kebutuhan akan aktualisasi diri merupakan tingkat kebutuhan yang tertinggi dari teori Maslow.

Aktualisasi diri yang di miliki oleh karyawan, juga perlu diberikan penghargaan atas prestasi kerjanya. Penghargaan merupakan imbalan yang di berikan oleh sekolah terhadap karyawan atas pekerjaan yang telah di lakukan, baik penghargaan yang sifatnya intrinsik maupun ekstrinsik.

Penghargaan yang baik, di harapkan mampu meningkatkan kinerja karyawan dan memiliki keinginan yang lebih tinggi untuk unggul dalam melakukan pekerjaan dan memiliki kemampuan untuk berkompetisi sehingga keseimbangan antara tujuan pribadi dan organisasi tercapai. Karena di sisi lain, penghargaan yang baik bisa juga menjadi motivasi tersendiri bagi karyawan tersebut untuk mencapai kinerja yang lebih baik kedepannya. Edison et al.,(2016:239) menjelaskan bahwa, sistem penghargaan berbicara tentang alokasi "reward"(biasanya dikaitkan erat dengan kenaikan gaji dan promosi) yang di dasarkan pada kriteria hasil kerja organisasi.

Komitmen karyawan pada organisasi tidak terjadi begitu saja, tetapi melalui proses yang cukup panjang dan bertahap. Selain itu, komitmen pada organisasi ditentukan oleh sejumlah faktor. Menurut Edison et al., (2016:221), mendefinisikan beberapa faktor yang mempengaruhi komitmen kerja karyawan pada organisasi adalah:

1) Faktor logis. Pegawai/karyawan akan bertahan dalam organisasi karena melihat adanya pertimbangan logis, misalnya memiliki jabatan strategi dan berpenghasilan cukup atau karena faktor kesulitan untuk mencari pekerjaan lain yang lebih baik lagi. 
2) Faktor lingkungan. Pegawai/ karyawan memiliki komitmen terhadap organisasi karena lingkungan yang menyenangkan, merasa di hargai, memiliki peluang untuk berinovasi, dan di libatkan dalam pencapaian tujuan organisasi.

3) Faktor harapan. Pegawai/ karyawan memiliki kesempatan yang luas untuk berkarier dan kesempatan untuk meraih posisi yang lebih tinggi, melalui sistem yang terbuka dan transparan

4) Faktor ikatan emosional. Pegawai/ karyawan merasa ada ikatan emosional yang tinggi, misalnya merasakan suasana kekeluargaan dalam organisasi, atau organisasi telah memberikan jasa yang luar biasa atas kehidupannya, atau dapat juga karena memiliki hubungan kerabat/ keluarga.

Karyawan yang sudah mempunyai ke tiga faktor tersebut, maka akan berkomitmen kerja yang tinggi terhadap organisasi/instansi tempat mereka bekerja, ini menunjukkan adanya kepuasan kerja yang terpenuhi, pada dasarnya dapat meningkatkan kinerja yang bersangkutan dan implikasinya adalah memudahkan strategis organisasi/ instansi untuk mencapai tujuan.

SMK 1 Kedungwuni Kab. Pekalongan masih banyak ditemukan karyawan yang belum di berikan penghargaan sehingga karyawan belum menunjukkan aktualisasi dirinya dengan baik dan berkomitmen kerja belum timbul adanya kinerjayang baik. Masih banyak pekerjaan yang belum terselesaikan dengan cepat dan tepat, sehingga karyawan perlu di berikan penghargaan atas kinerjanya selama ini agar mereka bisa menunjukkan aktualisasi dirinya dan berkomitmen kerja dengan baik sehingga banyak timbul kinerja karyawan yang di harapkan oleh sekolah.

\section{Kajian Pustaka}

\subsection{Kinerja Karyawan}

Edison et al., (2016:188), mendefinisikan kinerja adalah hasil dari suatu proses yang mengacu dan di ukur selama periode waktu tertentu berdasarkan ketentuan atau kesepakatan yang telah ditetapkan sebelumnya.

Wijayanti (2016:109), kinerja merupakan pencapaian yang optimal sesuai dengan potensi yang di miliki oleh seorang karyawan merupakan hal yang selalu menjadi perhatian para pemimpin organisasi. Sedarmayanti (2017:323) Mendefinisikan penilaian kinerja mengacu pada sistem formal dan terstruktur, di gunakan untuk mengukur, menilai, mempengaruhi sifat yang berkaitan dengan pekerjaan, perilaku dan hasil, termasuk tingkat ketidakhadiran.

Edison (2016:192) menyatakan bahwa terdapat beberapa aspek dimensi untuk mengukur kinerja karyawan, adalah:

a) Target adalah fokus pada pencapaian target, pekerjaan, atau jumlah uang yang di hasilkan.

b) Kualitas adalah tingkat kesalahan, kerusakan, dan kecermatan.

c) Penggunaaan waktu dalam kerja adalah tingkat ketidakhadiran, keterlambatan, waktu kerja efektif.

d) Taat asas adalah pekerjaan yang harus di lakukan dengan cara yang benar, transparan, dan dapat di pertanggungjawabkan. 


\subsection{Aktualisasi Diri}

Sutrisno (2009:126), menjelaskan apabila semua kebutuhan lainnya telah terpenuhi secara memadai, karyawan akan termotivasi oleh kebutuhan akan aktualisasi diri. Mereka akan mencari makna dan perkembangan pribadi dalam pekerjaannya, serta secara aktif mencari tanggung jawab baru.Maslow (1970) dalam bukunya Hierarchy of Needs menggunakan istilah aktualisasi diri (self actualization) sebagai kebutuhan dan dan pencapaian tertinggi seorang manusia. Menurut Fahmi (2015:102), menjelaskan teori Abraham H. Maslow, ada 5 (lima) kebutuhan manusia yang harus di susun dalam suatu bentuk hierarki yaitu:

1. Physiological needs( kebutuhan fisiologi),

2. Safety needs atau security needs( kebutuhan akan rasa aman),

3. Affection needs atau love needs atau belonging needs( kebutuhan rasa memiliki,sosial, dan cinta),

4. Esteem needs( kebutuhan harga diri),

5. Self-actualization( kebutuhan aktualisasi diri).

Sutrisno (2009:125) menyatakan bahwa indikator kebutuhan aktualisasi diri adalah sebagai berikut:

a) Kebutuhan pertumbuhan (growth need)

Kebutuhan pertumbuhan adalah kebutuhan untuk mengetahui dan memahami sesuatu, untuk tumbuh dan berkembang dengan menghargai orang lain.

b) Kebutuhan pencapaian potensi seseorang (achieving one's potential) Yaitu kebutuhan seseorang untuk mengembangkan potensi, kemampuan, dan bakat yang ada di dalam diri sendiri secara maksimal.

c) Kebutuhan pemenuhan diri (self-fulfillment)

Yaitu kebutuhan untuk memenuhi keberadaan diri dengan se maksimalkan penggunaan kemampuan dan potensi yang ada di dalam diri sendiri.

d) Kebutuhan dorongan

Yaitu dorongan dalam diri individu untuk mempertahankan keberadaan dirinya sesuai dengan potensi yang di miliki.

\subsection{Penghargaan}

Penghargaan atau sering di sebut dengan kompensasi merupakan bentuk pemberian balas jasa yang di berikan kepada seorang karyawan atas prestasi pekerjaan yang di lakukan, baik secara finansial maupun non finansial (Fahmi,2015:64). Edison et al.,(2016:239) menjelaskan bahwa, sistem penghargaan berbicara tentang alokasi "reward" (biasanya dikaitkan erat dengan kenaikan gaji dan promosi) yang di dasarkan pada kriteria hasil kerja organisasi. Menurut Wijayanti et al., (2016:108) memandang penghargaan sebagai sebuah sistem yang memberikan kontribusi terhadap kinerja dengan memghubungkan kepentingan karyawan kepada mereka yang berasal dari tim dan organisasi, sehingga meningkatkan usaha dan kinerja. 
Wijayanti et al., (2016:110) menyatakan bahwa dimensi penghargaan ada 3, yaitu:

a) Penghargaan ekstrinsik langsung terdiri atas gaji, upah, dan imbalan.

b) Penghargaan ekstrinsik tidak langsung terdiri dari program proteksi, bayaran di luar jam kerja, dan fasilitas-fasilitas untuk karyawan.

c) Penghargaan intrinsik terdiri atas rasa aman dalam pekerjaan, simbol status, dan harga diri.

\subsection{Komitmen Kerja}

Edison et al., (2016:220) komitmen sebagai, "kekuatan relatif identifikasi dengan individu dan keterlibatan dalam organisasi tertentu". Yusuf \& Darman Syarif(2018:27). Menjelaskan bahwa komitmen adalah sebuah dimensi perilaku yang penting dan dapat di gunakan untuk menilai keterikatan karyawan pada perusahaan.

Yusuf \& Darman Syarif (2018:33), ada 3 dimensi komitmen kerja:

a) Kemauan karyawan, dimana adanya keinginan karyawan untuk mengusahakan agar mencapai kepentingan organisasi.

b) Kesetiaan karyawan, dimana karyawan menginginkan untuk mempertahankan anggotanya untuk terus menjadi salah satu dari bagian organisasi

c) Kebanggaan karyawan, di tandai dengan karyawan merasa bangga telah menjadi bagian dari organisasi yang telah di ikutinya dan merasa bahwa organisasi tersebut telah menjadi bagian dalam hidupnya.

\section{Kerangka Pemikiran dan Perumusan Hipotesis}

\subsection{Kerangka Pemikiran}

Pada dalam sebuah instansi karyawan harus di tuntut bekerja dengan se maksimal mungkin untuk menciptakan kinerja dengan baik. Kinerja karyawan yang baik timbul karena adanya semangat kerja karyawan sehingga mencapai tujuan. Namun kinerja tersebut tidak muncul dengan sendirinya tetapi ada faktor-faktor yang mempengaruhinya, yaitu faktor internal dan faktor eksternal. kinerja karyawan yang baik timbul karena adanya aktualisasi diri, pemberian penghargaan, dan berkomitmen kerja yang baik terhadap instansi/ organisasi mereka bekerja. Aktualisasi diri berpengaruh terhadap kinerja karyawan. Aktualisasi diri karyawan harus di lihat secara objektif dan tidak di pandang sebelah mata. Masing-masing dari karyawan pasti memiliki kelebihan dan kekurangan dalam bekerja. Dengan kelebihan dan kekurangan tersebut, maka aktualisasi diri akan di tunjukan dengan cara berbeda beda sesuai dengan potensi yang di milikinya. Mereka akan terdorong untuk menjadi yang terbaik dari apa yang bisa di lakukannya.

Fahmi (2015:102), menjelaskan teori Abraham H. Maslow, ada 5 (lima) kebutuhan manusia yang harus di susun dalam suatu bentuk hierarki yaitu Physiological needs (kebutuhan fisiologi), Safety needs atau security needs (kebutuhan akan rasa aman), Affection needs atau love needs atau belonging needs (kebutuhan rasa memiliki,sosial, dan cinta), Esteem needs (kebutuhan harga diri), Self-actualization( kebutuhan aktualisasi diri).

Selain faktor aktualisasi diri, karyawan juga di berikan penghargaan atas kinerja yang telah di capainya.Penghargaan merupakan imbalan yang di berikan oleh sekolah terhadap karyawan atas pekerjaan yang telah di lakukan, baik penghargaan yang sifatnya intrinsik maupun ekstrinsik. 
Dengan adanya penghargaan yang baik di harapkan karyawan mampu meningkatkan kinerja dan memiliki keinginan yang lebih tinggi untuk unggul dalam melakukan pekerjaan dan memiliki kemampuan untuk berkompetisi sehingga keseimbangan antara tujuan pribadi dan organisasi tercapai.

Selain faktor aktualisasi diri dan penghargaan, komitmen kerja juga berpengaruh terhadap kinerja. Seseorang yang mempunyai komitmen kerja yang tinggi pada umumnya memiliki etos kerja yang baik. Mereka tidak tergantung pada atasan, di kantor ataupun tidak di kantor mereka akan tetap bekerja sesuai dengan tugas yang di berikannya. Sebagai wujud karyawan untuk berkomitmen kerja pada instansi yang mereka bekerja.

Jika karyawan mempunyai komitmen kerja yang tinggi terhadap organisasi/instansi tempat mereka bekerja, ini menunjukkan adanya kepuasan kerja yang terpenuhi, pada dasarnya dapat meningkatkan kinerja yang bersangkutan dan implikasinya adalah memudahkan strategis organisasi/ instansi untuk mencapai tujuan.

Berdasarkan keterangan uraian hubungan antar variabel terkait yang telah di jelaskan tersebut di atas, maka peneliti dapat merumuskan kerangka pemikiran yaitu sebagai berikut:

Gambar 1

Kerangka Pemikiran

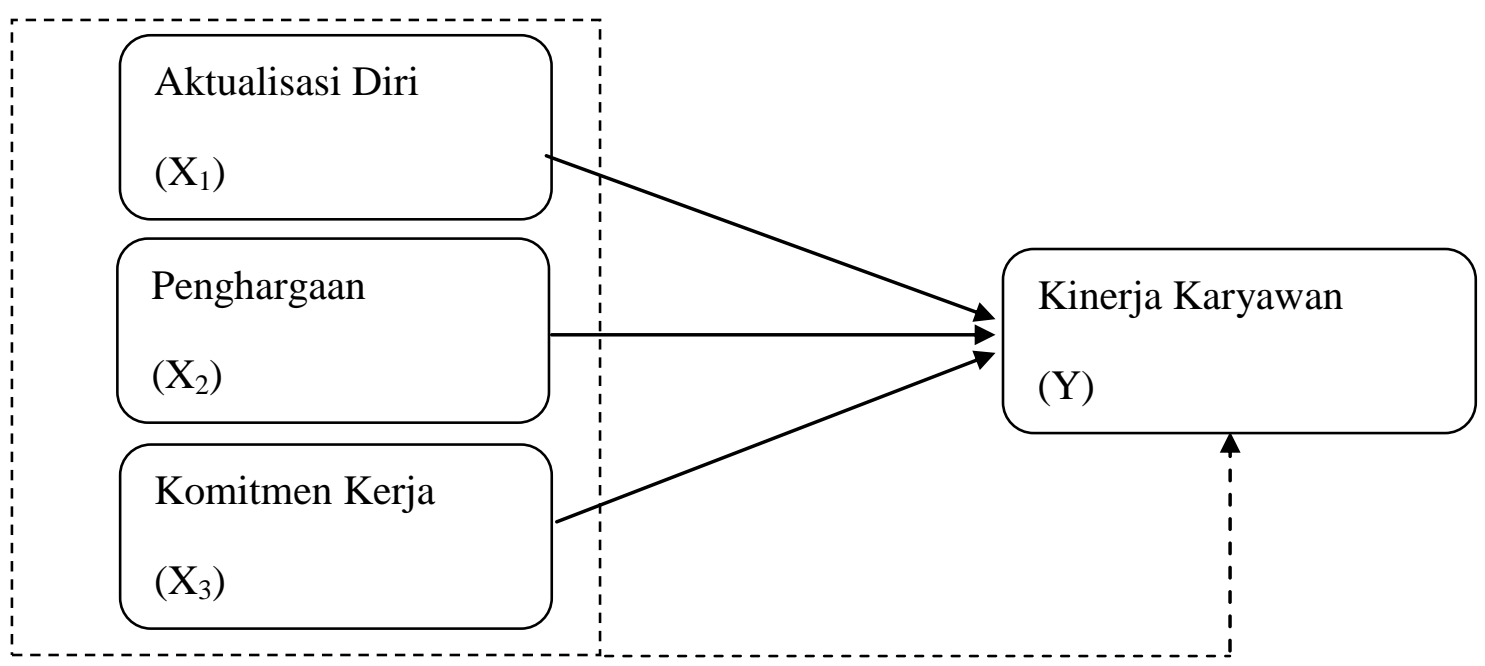

\subsection{Hipotesis}

$\mathrm{H}_{1}$ : Terdapat pengaruh aktualisasi diri terhadap kinerja karyawan di SMK 1 Kedungwuni Kab. Pekalongan

$\mathrm{H}_{2}$ : Terdapat pengaruh penghargaan terhadapkinerja karyawan di SMK 1 Kedungwuni Kab. Pekalongan

$\mathrm{H}_{3}$ : Terdapat pengaruh komitmen kerja terhadapkinerja karyawan di SMK 1 Kedungwuni Kab. Pekalongan

$\mathrm{H}_{4}$ : Terdapat pengaruh aktualisasi diri, penghargaan, dan komitmen kerja secara bersama-sama terhadapkinerja karyawan di SMK 1 Kedungwuni Kab. Pekalongan.

\section{Metode Penelitian}

\subsection{Pemilihan Metode}

Bentuk penelitian ini adalah penelitian diskriptif kuantitatif yaitu penelitian berupa data yang berbentuk angka-angka, meskipun juga berupa data kualitatif 
sebagai pendukungnya, seperti kata-kata atau kalimat yang tersusun dalam angket, dan wawancara antar peneliti.

Data kuantitatif merupakan data penelitian berupa angka atau data kualitatif yang diangkakan.Data kualitatif yang diangkakan misalnya terdapat dalam skala pengukuran.

\subsection{Lokasi Penelitian}

Lokasi Penelitian bertempat di SMK 1Kedungwuni Jalan Raya Paesan Utara Kedungwuni Kabupaten Pekalongan.

\subsection{Populasi dan Sampel}

Sugiyono (2008:96), populasi merupakan wilayah generalisasi yang terdiri atas objek atau subjek yang mempunyai kualitas dan karakteristik tertentu yang di tetapkan oleh peneliti untuk di pelajari dan kemudian di tarik kesimpulannya. Adapun jumlah populasi yang akan di teliti bagian Tata Usaha sebanyak 30 karyawan. Menurut Sugiyono (2008:97), Sampel adalah sebagian populasi yang di ambil sumber data dan dapat mewakili seluruh populasi. Teknik pengambilan sampel menggunakan sampling jenuh dimana sampling jenuh merupakan penentuan sampel bila semua anggota popoulasi. Data karyawan yang ada di SMK 1 Kedungwuni Kab. Pekalongan bagian Tata Usaha:

Tabel 1

Jumlah Karyawan bagian TU Di SMK 1 Kedungwuni

\begin{tabular}{|c|c|c|}
\hline No. & Jenis Kelamin & Jumlah Karyawan \\
\hline 1. & Laki- laki & 20 \\
\hline 2. & Perempuan & 10 \\
\hline
\end{tabular}

Sumber: Data Diolah

\subsection{Definisi Operasional Variabel}

Definisi operasional adalah terdiri dari upaya mereduksi konsep dari tingkat abstraksi ( tidak jelas ) menuju ke tingkat yang lebih konkret, dengan jalan merinci atau memecah menjadi dimensi kemudian elemen, diikuti dengan upaya menjawab pertanyaan - pertanyaan apa yang terkait dengan elemen elemen, dimensi dari suatu konsep.Beberapa variabel yang termasuk dalam penelitian ini antara :

Tabel 2

Definisi Operasional Variabel

\begin{tabular}{|c|c|c|c|}
\hline Variabel & Dimensi & Indikator & $\begin{array}{c}\text { No. Item } \\
\text { Pertanyaan }\end{array}$ \\
\hline \multirow{6}{*}{$\begin{array}{l}\text { Kinerja } \\
\text { Karyawan } \\
(\mathrm{Y})\end{array}$} & \multirow[t]{3}{*}{ Target } & 1. Pencapaian target & 1 \\
\hline & & 2. Pekerjaan yang baik & 2 \\
\hline & & $\begin{array}{l}\text { 3. Jumlah uang yang } \\
\text { dihasilkan }\end{array}$ & 3 \\
\hline & \multirow[t]{3}{*}{ KualitasKerja } & 1. Tingkat kesalahan & 4 \\
\hline & & 2. Kerusakan & 5 \\
\hline & & 3. Kecermatan & 6 \\
\hline
\end{tabular}




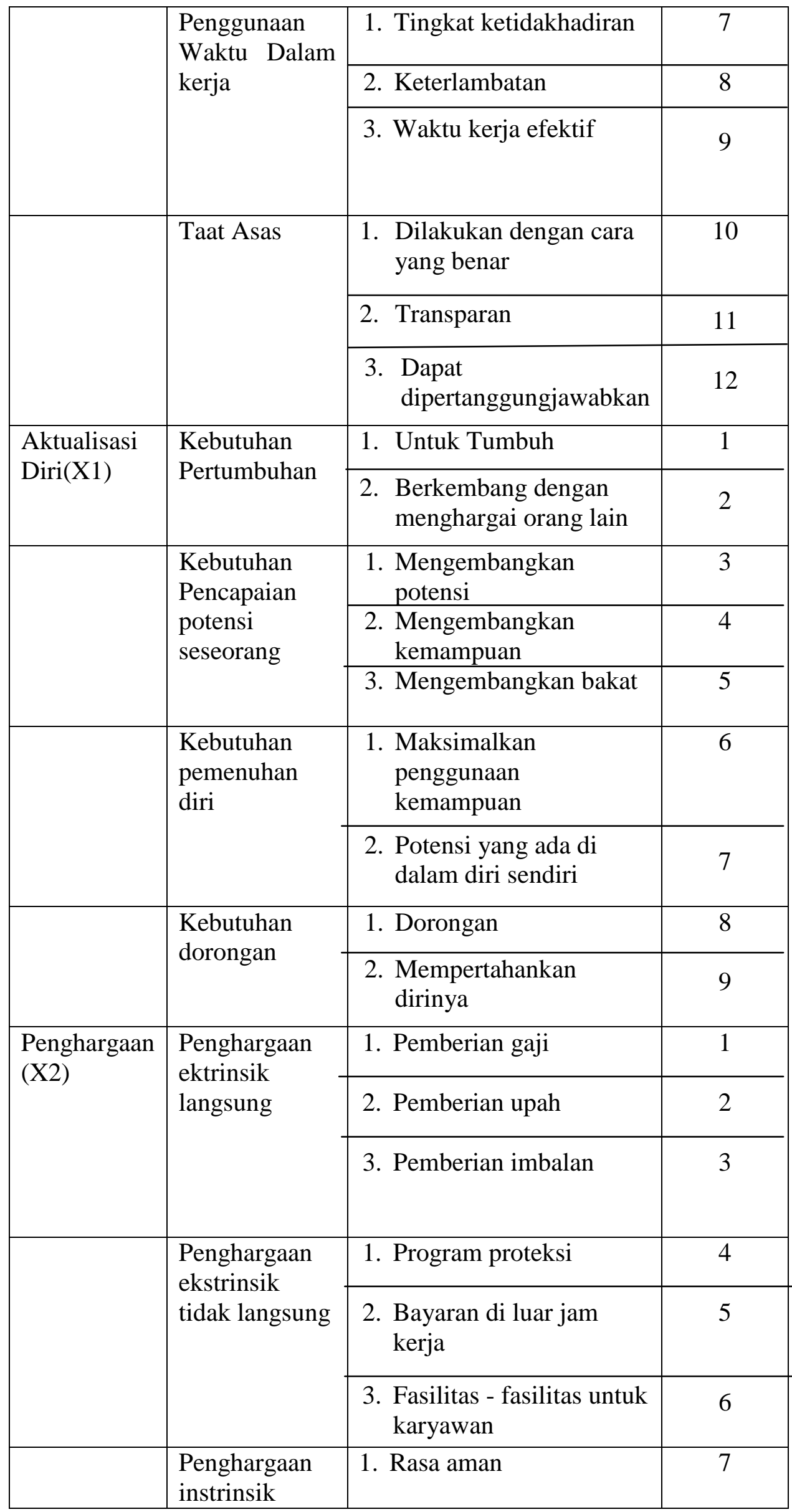




\begin{tabular}{|c|c|c|c|}
\hline & & 2. Simbol status & 8 \\
\hline & & 3. Harga diri & 9 \\
\hline Komitmen & Kemauan & 1. Keinginan Karyawan & 1 \\
\hline kerja (X3) & karyawan & $\begin{array}{l}\text { 2. Mencapai kepentingan } \\
\text { organisasi }\end{array}$ & 2 \\
\hline & $\begin{array}{l}\text { Kesetiaan } \\
\text { karyawan }\end{array}$ & $\begin{array}{l}\text { 1. Mempertahankan } \\
\text { anggota }\end{array}$ & 3 \\
\hline & & $\begin{array}{l}\text { 2. Menjadi bagian } \\
\text { organisasi }\end{array}$ & 4 \\
\hline & Kebanggaan & 1. Merasa bangga & 5 \\
\hline & Kal yawdil & $\begin{array}{l}\text { 2. Menjadi bagian dari } \\
\text { organisasi }\end{array}$ & 6 \\
\hline
\end{tabular}

\subsection{Teknik Pengumpulan Data}

Metode pengumpulan data merupakan metode atau cara yang digunakan peneliti untuk mendapatkan data dalam suatu penelitian. Instrumen penelitian adalah mengumpulkan data tentang aktualisasi diri, penghargaan, dan komitmen kerja terhadap kinerja karyawan.Untuk menguji hipotesis, di perlukan data yang benar, cermat, serta akurat karena absahan hasil penguji hipotesis tergantung pada kebenaran dan ketepatan data.

Dalam penelitian ini di gunakan uji coba angket yang di harapkan sebagai alat ukur penelitian yang di gunakan untuk mencapai kebenaran atau mendekati kebenaran.Angket yang di gunakan adalah skala linkert. Jawaban dari responden di bagi dalam 5 kategori penilaian dimana masing-masing pertanyaan di beri skor 1 sampai 5, antara lain:

\begin{tabular}{|l|c|}
\hline \multicolumn{1}{|c|}{ Jawaban } & Skor \\
\hline Sangat Setuju & 5 \\
\hline Setuju & 4 \\
\hline Kurang Setuju & 3 \\
\hline Tidak Setuju & 2 \\
\hline Sangat Tidak Setuju & 1 \\
\hline
\end{tabular}

\subsection{Teknik Pengolahan Data}

Dalam penelitian ini, tehnik pengolahan data yang di gunakan adalah tehnik regresi linier berganda yang di lakukan dengan bantuan program pengolahan data statistic yaitu Statistical Product and Service Solution (SPSS) versi 22.

\subsection{Metode Analisis Data}

Analisis kuantitatif adalah analisis data dalam bentuk angka-angka yang pembahasannya, melalui penghitungan statistik berdasarkan jawaban kuesioner dari responden. Hasil penghitungan dari skor atau nilai tersebut kemudian dalam analisis statistik yang dilakukan dengan bantuan program SPSS untuk membuktikan hubungan dan pengaruh antara variabel - variabel penelitian, dengan melakukan uji data sebagai berikut: 
a) Uji Validitas

Digunakan untuk mengukur sah atau tidaknya suatu kuesioner. Uji validitas dilakukan untuk memastikan bahwa masing - masing pertanyaan akan terklarifikasi pada variabel - variabel yang telah ditentukan.

b) Uji reliabilitas

dilakukan untuk mengetahui sejauh mana hasil pengukuran tetap konsisten, jika dilakukan pengukuran dua kali atau lebih terhadap gejala dengan gejala yang sama dengan menggunakan alat ukur yang sama. Uji reliabilitas dilakukan dengan menghitung cronbach alpha dari masing masing instrumen dalam suatu variabel. Instrumen yang dipakai dikatakan andal ( reliable) jika memiliki nilai croncbach alpha lebih dari 0,60.

c) Uji Asumsi Klasik

Uji asumsi klasik harus dilakukan untuk menguji layak tidaknya model analisis regresi yang digunakan dalam penelitian. Uji ini meliputi:

1) Uji Multikolinieritas

Bertujuan untuk menguji ada tidaknya korelasi antara variabel bebas. Jika variabel bebas saling berkorelasi di atas 0,09 mengindikasikan terjadinya multikolinieritas. Model regresi mensyaratkan tidak terjadinya multikolinieritas

2) Uji Heteroskedastisitas

Bertujuan untuk menguji apakah dalam model regresi terjadi ketidaksamaan varian dari residual satu pengamatan ke pengamatan lain. Model regresi mensyaratkan tidak terjadi heteroskedastisitas.

3) Uji Normalitas

Menurut Ghozali(2018:161), menjelaskan uji normalitas bertujuan untuk menguji apakah dalam model regresi, variabel pengganggu atau rasidual memiliki distribusi normal. Seperti diketahui bahwa uji t dan F mengasumsikan bahwa nilai residual mengikuti distribusi normal. Kalau asumsi ini di langgar maka uji statistik menjadi tidak valid untuk jumlah sampel kecil.

4) Analisis Regresi

Pengujian hipotesis dilakukan dengan persamaan regresi berganda, dengan rumus menurut Ghozali (2018:165):

$$
\begin{array}{ll}
\hat{\mathrm{Y}}=\mathrm{a}+\beta_{1} \mathrm{X}_{1}+ & \beta_{2} \mathrm{X}_{2}+\beta_{3} \mathrm{X}_{3}+\sum e \\
\text { Keterangan : } & \\
\hat{\mathrm{Y}} & =\text { Kinerja } \\
\mathrm{a} & =\text { konstanta } \\
\beta_{1} \beta_{2} \beta_{3} & =\text { koefisien regresi } \\
\mathrm{X} 1 & =\text { Aktualisasi Diri } \\
\mathrm{X} 2 & =\text { Penghargaan } \\
\mathrm{X} 3 & =\text { Komitmen Kerja } \\
\sum e & =\text { tingkat kesalahan }
\end{array}
$$

\section{Hasil Penelitian}

\subsection{Analisis Regresi Berganda}

Hasil analisis regresi di peroleh untuk mengetahui pengaruh utama antara variabel bebas (independen) dengan variabel terikat (dependen). 
Hasil perhitungan regresi linier berganda adalah sebagai berikut:

\section{Tabel 3}

\section{Analisis Regresi berganda}

\section{Coefficients $^{\mathrm{a}}$}

\begin{tabular}{|c|c|c|c|c|c|}
\hline \multirow[b]{2}{*}{ Model } & \multicolumn{2}{|c|}{$\begin{array}{l}\text { Unstandardized } \\
\text { Coefficients }\end{array}$} & \multirow{2}{*}{$\begin{array}{c}\text { Standardized } \\
\text { Coefficients } \\
\text { Beta }\end{array}$} & \multirow[b]{2}{*}{$t_{\text {hitung }}$} & \multirow[b]{2}{*}{ Sig. } \\
\hline & $\mathrm{B}$ & Std. Error & & & \\
\hline (Constant) & 10,889 & 5,358 & & 2,032 &, 052 \\
\hline Kebutuhan Aktualisasi Diri &, 606 & , 176 &, 528 & 3,444 &, 002 \\
\hline Penghargaan & , 107 & , 131 & , 124 &, 816 & ,422 \\
\hline Komitmen Kerja & , 473 & 254 & ,281 & 1,861 & 074 \\
\hline
\end{tabular}

a. Dependent Variable: Kinerja

Sumber: Data diolah SPSS 22

Rumus regresi linier berganda adalah sebagai berikut:

$\hat{\mathrm{Y}}=10,889+0,606 \mathrm{X}_{1}+0,107 \mathrm{X}_{2}+0,473 \mathrm{X}_{3}$

Dari hasil perhitungan regresi berganda ini di peroleh koefisien regresi sebagai berikut:

$\mathrm{a}=10,889$, adalah nilai konstanta dari persamaan kinerja karyawan $(\mathrm{Y})$ yang ada sebelum di pengaruhi terhadap aktualisasi diri $\left(\mathrm{X}_{1}\right)$, penghargaan $\left(\mathrm{X}_{2}\right)$, dan komitmen kerja $\left(\mathrm{X}_{3}\right)$.

$\beta_{1}=0,606$, menunjukan berpengaruh positif antara aktualisasi diri terhadap variabel kinerja karyawan, yang berarti jika dimensi aktualisasi diri meningkat maka akan mengakibatkan meningkatnya kinerja karyawan.

$\beta_{2}=0,107$, menunjukan berpengaruh positif antara penghargaan terhadap variabel kinerja karyawan, yang berarti jika dimensi penghargaan meningkat maka akan mengakibatkan meningkatnya kinerja karyawan.

$\beta_{3}=0,473$, menunjukan berpengaruh positif antara komitmen kerja terhadap variabel kinerja karyawan, yang berarti jika dimensi komitmen kerja meningkat maka akan mengakibatkan meningkatnya kinerja karyawan.

Hasil persamaan regresi berganda di atas dapat di ketahui bahwa peningkatan kinerja karyawan (Y) dipengaruhi secara positif dan signifikan oleh aktualisasi diri $\left(\mathrm{X}_{1}\right)$, penghargaan $\left(\mathrm{X}_{2}\right)$, dan komitmen kerja $\left(\mathrm{X}_{3}\right)$.

\subsection{Uji t (Parsial)}

a) Variabel Aktualisasi Diri $\left(\mathrm{X}_{1}\right)$

Nilai variabel aktualisasi diri adalah 3,444 sehingga dapat di simpulkan bahwa variabel aktualisasi diri berpengaruh positif dan signifikan $(0,002<0,05)$ secara parsial atau individu terhadap kinerja karyawan.

b) Variabel Penghargaan $\left(\mathrm{X}_{2}\right)$

Nilai variabel penghargaan adalah 0,816 sehingga dapat di simpulkan bahwa variabel penghargaan tidak berpengaruh positif dan signifikan $(0,422>0,05)$ secara parsial atau individu terhadap kinerja karyawan.

c) Variabel Komitmen Kerja $\left(\mathrm{X}_{3}\right)$

Nilai variabel komitmen kerja adalah 1,816 sehingga dapat di simpulkan 
bahwa variabel penghargaan tidak berpengaruh positif dan signifikan $(0,074>0,05)$ secara parsial atau individu terhadap kinerja karyawan.

\subsection{Uji F}

Untuk mengetahui kebenaran koefisien regresi berganda secara keseluruhan dengan uji F maka dihasilkan sebagai berikut:

Tabel 4

Hasil uji F

\begin{tabular}{|c|c|c|c|c|c|c|}
\hline \multicolumn{7}{|c|}{ ANOVA $^{a}$} \\
\hline & & $\begin{array}{l}\text { Sum of } \\
\text { Squares }\end{array}$ & df & Mean Square & $\mathrm{F}$ & Sig. \\
\hline \multirow[t]{3}{*}{$\frac{1}{1}$} & Regression & 370,083 & 3 & \multirow{3}{*}{$\begin{array}{r}123,361 \\
6,684\end{array}$} & \multirow[t]{3}{*}{18,456} & \multirow[t]{3}{*}{, $000^{b}$} \\
\hline & Residual & 173,784 & 26 & & & \\
\hline & Total & 543,867 & 29 & & & \\
\hline
\end{tabular}

a. Dependent Variable: Kinerja

b. Predictors: (Constant), Komitmen Kerja, Penghargaan, Kebutuhan Aktualisasi Diri

Sumber : data diolah SPSS 22

Perhitungan melalui olah data di peroleh nilai Funtuk komitmen kerja, penghargaan, dan kebutuhan aktualisasi diri sebesar 18,456, dengan tarif signifikasi 0,000 jauh lebih kecil dari 0,05.Sehingga hipotesis yang menyatakan bahwa variabel aktualisasi diri, penghargaan, dan komitmen berpengaruh signifikan terhadap kinerja karyawan di terima.

\subsection{Uji Determinasi R Square}

Tabel 5

Hasil uji $\mathrm{R}^{2}$

\section{Model Summary ${ }^{b}$}

\begin{tabular}{|c|c|c|c|c|c|c|c|c|c|}
\hline \multirow[b]{2}{*}{$\begin{array}{l}\text { Mod } \\
\text { el }\end{array}$} & \multirow[b]{2}{*}{$\mathrm{R}$} & \multirow[b]{2}{*}{$\begin{array}{c}\mathrm{R} \\
\text { Square }\end{array}$} & \multirow[b]{2}{*}{$\begin{array}{l}\text { Adjusted } \\
\text { R Square }\end{array}$} & \multirow{2}{*}{$\begin{array}{l}\text { Std. Error } \\
\text { of the } \\
\text { Estimate }\end{array}$} & \multicolumn{5}{|c|}{ Change Statistics } \\
\hline & & & & & $\begin{array}{c}\text { R Square } \\
\text { Change }\end{array}$ & $\begin{array}{c}F \\
\text { Change }\end{array}$ & df1 & df2 & $\begin{array}{c}\text { Sig. F } \\
\text { Change }\end{array}$ \\
\hline 1 &, $825^{\mathrm{a}}$ & ,680 & ,644 & 2,585 &, 680 & 18,456 & 3 & 26 &, 000 \\
\hline
\end{tabular}

a. Predictors: (Constant), Komitmen Kerja, Penghargaan, Kebutuhan Aktualisasi Diri

b. Dependent Variable: Kinerja

Sumber : Data di olah SPSS 22

Pengujian dengan determinasi majemuk berfungsi untuk mengukur persentase total di jelaskan oleh regresi. Ini berarti dapat di katakan penggunaan model koefisien determinasi $\left(R^{2}\right)$. Hasil $R^{2}=0,644$ berarti bahwa 64,4\% kinerja karyawan (Y) di pengaruhi oleh besarnya aktualisasi diri $\left(\mathrm{X}_{1}\right)$, penghargaan $\left(\mathrm{X}_{2}\right)$, dan komitmen kerja $\left(\mathrm{X}_{3}\right)$, sisanya sebesar $35,6 \%$ dipengaruhi oleh faktor lain di luar model. 


\section{Kesimpulan dan Saran}

\subsection{Kesimpulan}

Dari analisis data di atas, di peroleh hasil sebagai berikut:

1. Dari hasil uji validitas menunjukan bahwa ada 36 pertanyaan, dari semua pertanyaan tersebut menunjukan valid dan dapat di gunakan sebab $\mathrm{r}$ hitung lebih besar $r$ tabel.

2. Dari hasil reliabilitas menunjukan bahwa telah terjadi reliabel karena $r$ alpha lebih besar dari standar koefisien dan pertanyaan tersebut dinyatakan handal.

3. Dari hasil persamaan regresi berganda di ketahui bahwa peningkatan kinerja karyawan (Y) dipengaruhi secara positif dan signifikan oleh aktualisasi diri $\left(\mathrm{X}_{1}\right)$, penghargaan $\left(\mathrm{X}_{2}\right)$, komitmen kerja $\left(\mathrm{X}_{3}\right)$

4. Dari hasil perhitungan melalui olah data, besarnya $t_{\text {hitung }}$ aktualisasi diri $\left(\mathrm{X}_{1}\right)$ sebesar 3,444 dan $\mathrm{t}_{\text {tabel }}$ sebesar 2,056 maka $t_{\text {hitung }}$ lebih besar dari $t_{\text {tabel }}$ sehingga $\mathrm{H}_{0}$ di tolak, karena $\mathrm{H}_{0}$ di tolak maka hipotesis yang menyatakan bahwa aktualisasi diri berpengaruh secara signifikan terhadap kinerja karyawan di terima.

5. Dari hasil perhitungan melalui olah data, besarnya $t_{\text {hitung }}$ penghargaan 0,816 dan $\mathrm{t}_{\text {tabel }}$ sebesar 2,056 maka $\mathrm{t}_{\text {hitung }}$ lebih kecil dari $\mathrm{t}_{\text {tabel }}$ sehingga $\mathrm{H}_{0}$ di terima, karena $\mathrm{H}_{0}$ di terima maka hipotesis yang menyatakan bahwa penghargaan tidak pengaruh signifikan terhadap kinerja karyawan.

6. Dari hasil perhitungan melalui olah data, besarnya $t_{\text {hitung }}$ komitmen kerja 0,074 dan $\mathrm{t}_{\text {tabel }}$ sebesar 2,056 maka $\mathrm{t}_{\text {hitung }}$ lebih kecil dari $\mathrm{t}_{\text {tabel }}$ sehingga $\mathrm{H}_{0}$ di terima, karena $\mathrm{H}_{0}$ di terima maka hipotesis yang menyatakan bahwa komitmen kerja tidak pengaruh signifikan terhadap kinerja karyawan.

7. Dari hasil perhitungan melalui olah data di peroleh nilai $F_{\text {hitung }}$ untuk aktualisasi diri, penghargaan, komitmen kerja sebesar 18,456, dengan taraf signifikasi 0,000 jauh lebih kecil dari 0,05. Sedangkan besarnya $F_{\text {tabel }} 5,77$, maka $F_{\text {hitung }}$ lebih besar dari $F_{\text {tabel }}(18,456>5,77)$. Sehingga hipotesis yang menyatakan bahwa variabel aktualisasi diri, penghargaan, dan komitmen berpengaruh signifikan terhadap kinerja karyawan di terima.

8. Pengujian dengan determinasi maejemuk berfungsi untuk mengukur persentase total di jelaskan oleh regresi. Ini berarti dapat dikatakan penggunaan model koefisien determinasi $\left(\mathrm{R}^{2}\right)$,hasil $\mathrm{R}^{2}=0,644$ berarti bahwa 64,4\% kinerja karyawan (Y) di pengaruhi oleh besarnya aktualisasi diri $\left(\mathrm{X}_{1}\right)$, penghargaan $\left(\mathrm{X}_{2}\right)$, dan komitmen kerja $\left(\mathrm{X}_{3}\right)$, sisanya sebesar 35,6\% dipengaruhi oleh faktor lain di luar model.

9. Berdasarkan tabel di atas, maka di peroleh pengaruh paling dominan adalah variabel aktualisasi diri dengan nilai koefisien 0,528 dimana nilai ini paling besar di bandingkan dengan variabel lain.

10.

\subsection{Saran}

Berdasarkan kesimpulan yang ada, maka penulis menyampaikan beberapa saran yang berkaitan dengan kinerja karyawan di SMK 1 Kedungwuni Kab. Pekalongan, agar dapat di gunakan sebagai pertimbangan bagi pihak sekolah dan peneliti lebih lanjut sebagai berikut :

1. Bagi Sekolah

Pihak Kepala Sekolah SMK 1 Kedungwuni sebaiknya melakukan pembenahan kinerja karyawan dan memperhatikan lagi sarana dan 
prasarana apa yang di butuhkan karyawan, sehingga karyawan dapat mengaktualisasikan diri dalam sekolah terutama dalam hal potensi dalam diri karyawan. SMK 1 Kedungwuni juga perlu memperhatikan penghargaan dan komitmen kerja terhadap karyawannya dalam pemberian tunai dan non tunai dalam bentuk materi dalam hal pemberian cuti

2. Bagi Peneliti Selanjutnya

Untuk penelitian yang selanjutnya di sarankan peneliti melakukan penelitian dengan menambah beberapa variabel lagi seperti variabel beban kerja yang berhubungan dengan skripsi ini serta mengkaji lebih jauh lagi tentang aktualisasi diri, penghargaan, dan komitmen kerja terhadap kinerja karyawan dari di sekolah lain khususnya di sekolah SMK 1 Kedungwuni Kab. Pekalongan.

\section{DAFTAR PUSTAKA}

Djawa, E. M. (2016). Pengaruh Motivasi Kerja Dan Komitmen Kerja Karyawan Terhadap Kepuasan Kerja Para Pegawai Bappedas Di Kabupaten Nagekeo. Jurnal Ilmu Manajemen, Vol. 3, No. 2, 1-26.

Edison, E., Anwar, Y., \& Komariyah, I. (2016). Manajemen Sumber Daya Manusia. Bandung: Alfabeta.

Fahmi, I. (2015). Manajemen Sumber Daya Manusia . Bandung: Alfabeta.

Ghozali, I. (2018). Aplikasi Analisis Multivarite, Dengan Program IBM SPSS 25. Semarang: Badan Penerbit Universitas Diponegoro Semarang.

Pane, S. G., \& Fatmawati. (2017). Pengaruh Komitmen Organisasi Terhadap Kinerja Pegawai Pada Badan Pertanahan Naional Kota Meda. Jurnal Riset Manajemen Bisnis, Vol. 2, No. 4, 67-79.

Panus. (2015). Pengaruh Kebutuhan Aktualisasi Diri, Penghargaan, dan Sosial Terhadap

Prestasi Kerja Karyawan Pada PT. Bank Sulselbar Kantor Pusat Makassar. Jurnal Ilmu Manajemen , Vol. 4, No. 3, 1-15.

Priyono, \& Marnis. (2008). Manajemen Sumber Daya Manusia. Sidoarjo: Zitama.

Sedarmayanti. (2017). Sumber Daya Manusia.Bandung: Refika Aditama

Sugiyono. (2012). Metode Penelitian Bisnis. Bandung: Alfabeta.

Sugiyono. (2008). Metode Penelitian Kuantitatif Dan Kualitatif. Bandung: Alfabeta.

Sutrisno, E. (2009). Manajemen Sumber Daya Manusia. Surabaya: Kencana.

Wijayanti, D. T., \& Prabu, A. S. (2016). Pengaruh Penghargaan Dan Motivasi Terhadap Kinerja Karyawan (Studi Pada Divisi Penjualan PT. United Motors Center Suzuki Ahmad Yani Surabaya). Ekonomi Bisnis Dan Kewirausahaan, 104-117. 
Yamanie, I. Y., \& Syaharuddin. (2016). Pengaruh Penilaian Prestasi Kerja, Komitmen Organisasi, Dan Disiplin Kerja Terhadap Kinerja Karyawan Pada PT. Pelabuhan Indonesia IV Cabang Samarinda. Jurnal Manajemen, Vol. 8 (1), 55-65.

Yusuf, R. M., \& Syarif, D. (2018). Komitmen Organisasi Cetakan Ke 2. Makassar: Nas Media Pustaka. 